Approved for public release; distribution is unlimited.

\title{
Mercury in Fish
}

\section{Collected Upstream and Downstream of}

Los Alamos National Laboratory,

New Mexico: 1991-2004

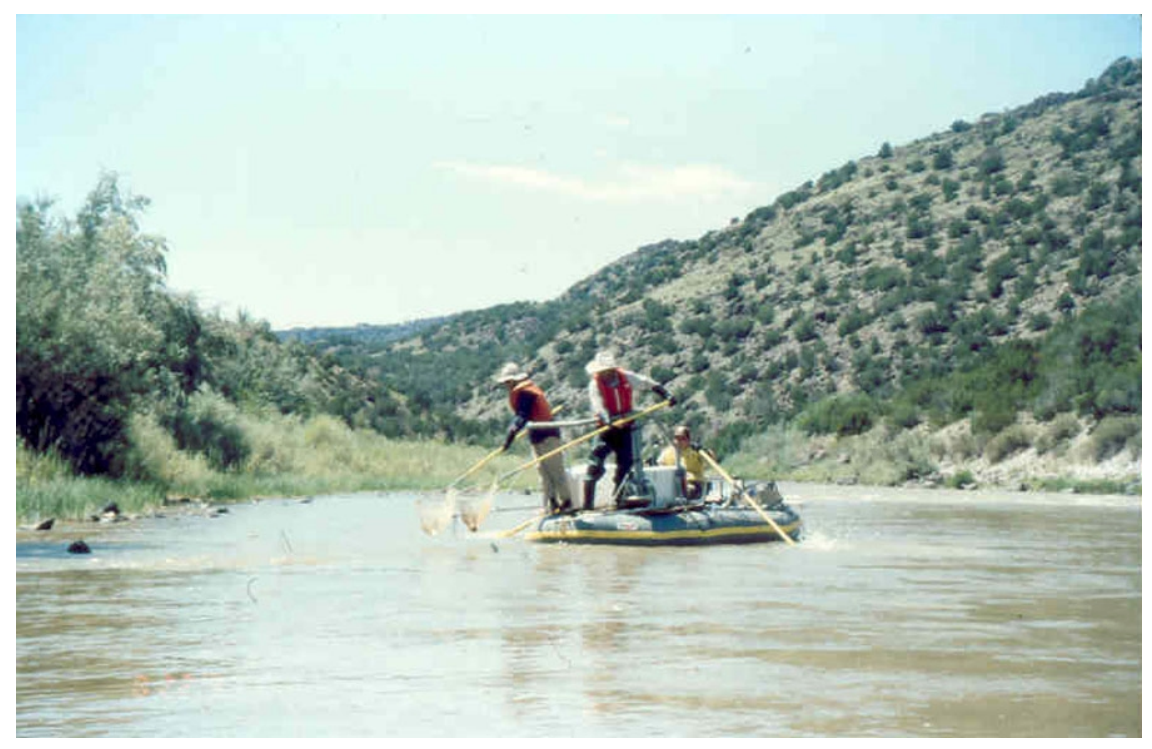




\section{Edited by Hector Hinojosa, Group IM-1}

Cover: Electrofishing on the Rio Grande.

Los Alamos National Laboratory, an affirmative action/equal opportunity employer, is operated by the University of California for the United States Department of Energy under contract W-7405-ENG-36.

This report was prepared as an account of work sponsored by an agency of the United States Government. Neither the Regents of the University of California, the United States Government nor any agency thereof, nor any of their employees make any warranty, express or implied, or assume any legal liability or responsibility for the accuracy, completeness, or usefulness of any information, apparatus, product, or process disclosed, or represent that its use would not infringe privately owned rights. Reference herein to any specific commercial product, process, or service by trade name, trademark, manufacturer, or otherwise does not necessarily constitute or imply its endorsement, recommendation, or favoring by the Regents of the University of California, the United States Government, or any agency thereof. The views and opinions of authors expressed herein do not necessarily state or reflect those of the Regents of the University of California, the United States Government, or any agency thereof. Los Alamos National Laboratory strongly supports academic freedom and a researcher's right to publish; as an institution, however, the Laboratory does not endorse the viewpoint of a publication or guarantee its technical correctness. 
LA-14172

Issued: October 2004

Mercury in Fish

Collected Upstream and Downstream of

Los Alamos National Laboratory,

New Mexico: 1991-2004

P.R. Fresquez

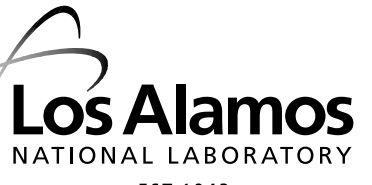

The World's Greatest Science Protecting America 



\title{
MERCURY IN FISH COLLECTED UPSTREAM AND DOWNSTREAM OF LOS ALAMOS NATIONAL LABORATORY, NEW MEXICO: 1991-2004
}

by

\author{
P.R. Fresquez
}

\begin{abstract}
Small amounts of mercury (Hg) may exist in some canyon drainage systems within Los Alamos National Laboratory lands as a result of past discharges of untreated effluents. This paper reports on the concentrations of $\mathrm{Hg}$ in muscle (fillets) of various types of fish species collected downstream of LANL's influence from 1991 through 2004. The mean $\mathrm{Hg}$ concentration in fish from Cochiti reservoir $(0.22 \mu \mathrm{g} / \mathrm{g}$ wet weight), which is located downstream of LANL, was similar to fish collected from a reservoir upstream of LANL (Abiquiu) (0.26 $\mu \mathrm{g} / \mathrm{g}$ wet weight). Mercury concentrations in fish collected from both reservoirs exhibited significantly (Abiquiu $=\mathbf{p}<0.05$ and Cochiti $=$ $p<0.10)$ decreasing trends over time. Predator fish like the northern pike (Esox lucius) contained significantly higher concentrations of $\mathbf{H g}$ $(0.39 \mu \mathrm{g} / \mathrm{g}$ wet weight) than bottom-feeding fish like the white sucker (Catostomus commersoni) $(0.10 \mu \mathrm{g} / \mathrm{g}$ wet weight).
\end{abstract}

\section{INTRODUCTION}

During the early years of Los Alamos National Laboratory (LANL) operations, some canyon drainage systems, which are major pathways for contaminants to reach offsite receptors, received various amounts of untreated waste effluents (Purtymun, 1974; Hakonson et al., 1980; Fresquez et al., 1995; Bennett et al., 1996). As a result, some of these canyons contain small amounts of light, heavy, and nonmetal trace elements, including mercury $(\mathrm{Hg})$ (Hakonson et al., 1980). Although most of the runoff and/or effluent flow in the canyons are lost to the underlying alluvium and to evapotranspiration before leaving LANL lands (Stephens et al., 1993), some flow from excessive storm events may reach the Rio Grande (RG) (Abeele et al., 1981). The RG is the main tributary in New Mexico (NM) and traverses approximately 750 river miles from its 
headwaters in the San Juan Mountains in southwestern Colorado, through the State of NM, to El Paso, Texas, and beyond to the Gulf of Mexico (Ellis et al., 1993).

Mercury concentrations in fish occurring in rivers, lakes, and reservoirs in NM have been of significant concern to the public for a number of years (Torres, 1998); there are currently 26 fish advisories for $\mathrm{Hg}$ in $\mathrm{NM}$ waters based on the $1 \mathrm{ppm}(\mu \mathrm{g} / \mathrm{g})$ wet weight (w w) Food and Drug Administration (FDA) action limit (NMDH, 1993). The main source of $\mathrm{Hg}$ into water systems is from atmospheric deposition resulting from natural degassing of the earth's crust (2,700 to 6,000 tons of $\mathrm{Hg}$ annually) and burning of fossil fuels (2,000 to 3,000 tons of $\mathrm{Hg}$ annually) (Foulke, 1994). Although the concentration of $\mathrm{Hg}$ in all but a few small, often ephemeral, rivers and streams in NM are very low (NMED 1999), inorganic Hg existing in the water is converted to methyl mercury- $\left(\mathrm{CH}_{3}\right) \mathrm{Hg}^{+}$, a neurotoxin - under anaerobic conditions by sulfate reducing bacteria (Driscoll et al., 1994; Bunce, 1991). Methyl mercury is fat and water soluble, which is easily taken up by living cells (Hammond and Foulkes, 1986); it is the main form of $\mathrm{Hg}$ in fish (95\%) (Driscoll et al., 1994); and it bioaccumulates (e.g., larger fish > smaller fish) (Bache et al., 1971) and biomagnifies (e.g., carnivorous fish $>$ omnivorous fish $>$ herbivorous fish) readily (Ochiai, 1995).

As part of the environmental surveillance program at LANL, fish have been collected on an annual basis upstream and downstream of LANL to determine if there are any contaminants arising in these important resources as a result of Laboratory operations (Fresquez et al., 1994, 1999a, 1999b; Gonzales et al., 1999). The purpose of this paper is to report the concentrations of $\mathrm{Hg}$ in muscle (fillet) tissues of various fish species and trophic levels collected at Abiquiu reservoir (AR), which is upstream of LANL, and at Cochiti reservoir (CR), which is downstream of LANL, from 1991 through 2004.

\section{MATERIALS AND METHODS}

Fish were collected using gill nets from AR, a 4,290-acre impoundment located on the Rio Chama approximately 40 miles upstream of LANL, and CR, an 11,000-acre flood and sediment control project located on the Rio Grande approximately eight miles downstream of LANL from 1991 through 2003. All fish were placed into large plastic bags following collection, marked for identification, and transferred to LANL in an ice 
chest cooled to $4^{\circ} \mathrm{C}$. In the laboratory, a subsample ( $\sim 25 \mathrm{~g}$ wet) of muscle (fillet) from each fish was placed into a quart size Ziploc ${ }^{\circledR}$ plastic bag and submitted to an analytical laboratory for analysis of $\mathrm{Hg}$. In 1991, samples were analyzed by the New Mexico Scientific Laboratory Division, Santa Fe; from 1994 through 1999, samples were analyzed by an internal LANL laboratory; and, from 2000 through 2003, samples were analyzed by Paragon Analytics, Inc., Fort Collins, Colorado. All methods of Hg analyses in fish have been described previously (Fresquez et al., 1994; Fresquez et al., 1996). Results are reported in $\mu \mathrm{g} / \mathrm{g} \mathrm{w} \mathrm{w}$.

Variations in the mean trace element content in muscle between fish species (e.g., catfish versus carp, etc.), trophic level (e.g., predator fish versus bottom-feeding fish), and reservoirs (e.g., AR versus CR) were assessed using a Wilcoxon Rank Sum Test at the 0.05 (Gilbert, 1987). Trend analysis for Hg concentrations over the 13-year period was completed using a Mann-Kendal test at the 0.05 and 0.10 probability level.

\section{RESULTS AND DISCUSSION}

Mercury concentrations in fish (fillets) collected from AR and CR over the years ranged from 0.03 to $1 \mu \mathrm{g} / \mathrm{g} \mathrm{w}$ w (Table 1). The highest $\mathrm{Hg}$ concentrations were detected in a catfish each from AR and CR in 1994. Based on the mean concentrations of $\mathrm{Hg}$ in fish over the years, pike contained the highest $(0.39 \mu \mathrm{g} / \mathrm{g} \mathrm{w} \mathrm{w})$ and white sucker contained the lowest $(0.10 \mu \mathrm{g} / \mathrm{g} \mathrm{w} w)$. The general order was as follows: northern pike (Esox lucius) $>$ small mouth bass (Micropterus dolomieu) $=$ crappie (Pomoxis annularis) $>$ walleye (Sander vitreus) $>$ trout (Salmo trutta) $>$ catfish (Ictalurus punctatus) $>$ carp (Cyprinus carpio) $>$ white bass (Morone chrysops) $>$ white sucker (Catostomus commersoni). Concentrations of $\mathrm{Hg}$ in catfish $(0.24 \mu \mathrm{g} / \mathrm{g} \mathrm{w} \mathrm{w})$ from this study were very similar to $\mathrm{Hg}$ levels in catfish collected from Conchas (averaged $0.25 \mu \mathrm{g} / \mathrm{g} \mathrm{w} \mathrm{w}$ ) and Santa Rosa (ranged from 0.22 to $0.33 \mu \mathrm{g} / \mathrm{g} \mathrm{w} \mathrm{w}$ ) lakes (Bousek, 1996; Torres, 1998). As a group and regardless of collection sites, $\mathrm{Hg}$ concentrations were significantly $(\mathrm{p}<0.05)$ higher in predator fish (average $=0.29 \mu \mathrm{g} / \mathrm{g} \mathrm{w} \mathrm{w}$ ) than in bottom-feeding fish (average $=$ $0.22 \mu \mathrm{g} / \mathrm{g} \mathrm{w}$ w). Because $\mathrm{Hg}$ normally biomagnifies up the food chain, carnivorous fish readily contain more $\mathrm{Hg}$ than omnivorous or herbivorous fish (Ochiai, 1995). 
Table 1. Descriptive statistics of mercury $(\mu \mathrm{g} / \mathrm{g} \mathrm{w}$ w) in muscle (fillet) of fish collected from reservoirs upstream and downstream of LANL from 1991 through 2003.

\begin{tabular}{lrccl}
\hline Fish Species & N & Minimum & Maximum & Mean (SD) $^{\mathbf{1}}$ \\
\hline Carp & 42 & 0.05 & 0.51 & $0.22(0.11) \mathrm{a}, \mathrm{d}$ \\
Catfish & 69 & 0.03 & 1.00 & $0.24(0.18) \mathrm{a}, \mathrm{b}$ \\
Crappie & 8 & 0.17 & 0.55 & $0.30(0.13) \mathrm{a}$ \\
Pike & 7 & 0.14 & 0.76 & $0.39(0.20) \mathrm{a}$ \\
Small Mouth Bass & 4 & 0.06 & 0.57 & $0.30(0.22) \mathrm{a}, \mathrm{c}$ \\
Trout & 4 & 0.04 & 0.33 & $0.25(0.14) \mathrm{a}, \mathrm{c}, \mathrm{e}$ \\
Walleye & 9 & 0.13 & 0.42 & $0.27(0.09) \mathrm{a}$ \\
White Bass & 6 & 0.12 & 0.23 & $0.19(0.04) \mathrm{b}, \mathrm{d}, \mathrm{e}$ \\
White Sucker & 11 & 0.03 & 0.25 & $0.10(0.06) \mathrm{c}$ \\
\hline
\end{tabular}

${ }^{1}$ Means within the same column followed by the same lower case letter were not significantly different at the 0.05 probability levels using a nonparametric Wilcoxon Rank Sum test.

Mercury concentrations in fish from CR, downstream of LANL, were similar in concentration of $\mathrm{Hg}$ in fish collected upstream of LANL (AR) (Table 2). With some notable (individual) exceptions, mean concentrations of $\mathrm{Hg}$ in fish from both $\mathrm{AR}$ and $\mathrm{CR}$ were within $\mathrm{Hg}$ concentrations typical of fish from nonpolluted fresh water systems (Abernathy and Cumbie, 1977) and below the FDA's action limit of $1 \mu \mathrm{g} \mathrm{Hg} / \mathrm{g} \mathrm{w}$ w (Torres, 1998). Overall, mean Hg concentrations in fish collected from both reservoirs show significantly decreasing trends over time; AR $(p=0.016)$ was significant at the 0.05 probability level and $C R(p=0.10)$ was significant at the 0.10 probability level. It is not completely known why concentrations of $\mathrm{Hg}$ are decreasing in fish collected from $\mathrm{AR}$ and $\mathrm{CR}$, but the reduction of emissions in coal-burning power plants and/or the reduction of carbon sources within the reservoirs may be but two of the reasons. Since the early 1980s, for example, coal burning power plants in the northwest corner of NM have been required to install benturi scrubbers and bag houses to capture particulates and reduce air emissions (Paul Martinez, personnel communication, Environmental Engineer Specialist, Air Quality Bureau, New Mexico Environment Department, September 22, 1999). A reduction in air emissions from regional sources employing pollution-control technologies that capture $\mathrm{Hg}$ was shown to be one of the principal factors in declining $\mathrm{Hg}$ levels over time observed in lakes in the Midwestern U.S. (Engstrom and Swain, 1997). Additionally, since the conversion of $\mathrm{Hg}$ to methyl mercury is primarily a biological 
process, it has been demonstrated that $\mathrm{Hg}$ concentrations in fish tissue rise significantly in impoundments that form behind new dams, and then gradually decline to an equilibrium level as the carbon provided by flooded vegetation is depleted (NMED, 1999).

Table 2. Mean ( \pm std dev) mercury ( $\mu \mathrm{g} / \mathrm{g}$ w w) concentrations in muscle (fillet) of fish collected from reservoirs upstream and downstream of LANL from 1991 through 2003.

\begin{tabular}{lcc}
\hline Year $^{1}$ & Abiquiu Reservoir & Cochiti Reservoir \\
\hline 1991 & $0.36(0.09) \mathrm{a}^{1}$ & $0.34(0.13) \mathrm{a}$ \\
1994 & $0.37(0.28) \mathrm{a}$ & $0.28(0.32) \mathrm{a}$ \\
1995 & $0.34(0.26) \mathrm{a}$ & $0.12(0.04) \mathrm{a}$ \\
1996 & $0.34(0.10) \mathrm{a}$ & $0.21(0.10) \mathrm{b}$ \\
1997 & $0.16(0.10) \mathrm{a}$ & $0.15(0.10) \mathrm{a}$ \\
1999 & $0.24(0.12) \mathrm{a}$ & $0.14(0.09) \mathrm{a}$ \\
2000 & $0.10(0.06) \mathrm{b}$ & $0.17(0.12) \mathrm{a}$ \\
2001 & $0.27(0.07) \mathrm{a}$ & $0.27(0.15) \mathrm{a}$ \\
2002 & $0.20(0.09) \mathrm{a}$ & $0.12(0.07) \mathrm{b}$ \\
2003 & $0.13(0.07) \mathrm{a}$ & $0.15(0.10) \mathrm{a}$ \\
Mean of Means $( \pm S D)$ & $0.26(0.16) \mathrm{A}^{2}$ & $0.22(0.16) \mathrm{A}$ \\
\hline${ }^{1}$ Means within the same row followed by the same lower case letter were not significantly \\
different at the 0.05 probability levels using a nonparametric Wilcoxon Rank Sum test. \\
${ }^{2}$ Means within the same column followed by the same upper case letter were not \\
significantly different at the 0.05 probability levels using a nonparametric Wilcoxon \\
Rank Sum test. (Note: since the test statistic was 0.069 this relationship was significantly \\
different at the 0.10 probability level.)
\end{tabular}

\section{CONCLUSIONS}

Mercury concentrations in fish collected from CR appear to be mostly a result of either natural and/or anthropogenic sources other than LANL. Bioaccumulation and biomagnification factors were probably the main reasons that larger predator fish like pike contained significantly higher levels of $\mathrm{Hg}$ than smaller bottom-feeding fish like the white sucker. Concentrations of $\mathrm{Hg}$ in fish collected from both reservoirs showed decreasing trends over time. 


\section{ACKNOWLEDGMENTS}

Thanks to all the people, such as Johnny Salazar (retired), Louis Naranjo, and Rick Velasquez, and to all of the summer students who participated in the collection of fish over the years. 


\section{REFERENCES}

Abeele, W.V., M.L. Wheeler, and B.W. Burton, "Geohydrology of Bandelier Tuff," Los Alamos Scientific Laboratory report LA-8962-MS (1981).

Abernathy, A.R., and P.M. Cumbie, "Mercury Accumulation by Largemouth Bass in Recently Impounded Reservoirs," Bulletin of Environ Contamination and Toxicology 17:595-602 (1977).

Bache, C.A., W.H. Gutenmann, and D.J. Lusk, "Residues of Total Mercury and Methylemercuric Salts in Lake Trout as a Function of Age," Science 172:951-952 (1971).

Bennett, K., J. Biggs, and P.R. Fresquez, "Radionuclide Contaminant Analysis of Small Mammals, Plants, and Sediments within Mortandad Canyon, 1994," Los Alamos National Laboratory report LA-13104-MS (1996).

Bousek, J., "An Analysis of Copper, Zinc, and Mercury Concentrations in Fish Species in Santa Rosa Reservoir, New Mexico," M.S. Thesis, New Mexico Institute of Mining and Technology, Socorro, NM (1996).

Bunce, N., Environmental Chemistry, Wuerz Publishing Ltd., New York, NY (1991).

Driscoll, C.T., C. Yan, C.L. Schofield, R.K. Munson, and J.G. Holsapple, “The Mercury Cycle and Fish in the Adirondack Lakes," Environmental Science and Technology 28:136-143 (1994).

Ellis, S.R., G.W. Levings, L.F. Carter, S.F. Richey, and M.J. Radell, "Rio Grande Valley, Colorado, New Mexico, and Texas," Water Resource Bulletin, American Water Resources Association 29:617-646 (1993). 
Engstrom, D.R., and E.B. Swain, "Recent Declines in Atmospheric Mercury Deposition in the Upper Midwest," Environmental Science and Technology 31:960-967 (1997).

Foulke, J.E., "Mercury in Fish: Cause for Concern," Food and Drug Administration Consumer, September (1994).

Fresquez, P.R., D.R. Armstrong, and J.G. Salazar, "Radionuclide Concentrations in Game and Nongame Fish Upstream and Downstream of Los Alamos National Laboratory: 1981 to 1993," Los Alamos National Laboratory report LA-12818-MS (1994).

Fresquez, P.R., T.E. Foxx, and L. Naranjo, Jr., "Strontium Concentrations in Chamisa (Chrysothamnus nauseosus) Shrub Plants Growing in a Former Liquid Waste Disposal Area in Bayo Canyon," Los Alamos National Laboratory report LA-13050-MS (1995).

Fresquez, P.R., D.R. Armstrong, and L. Naranjo, Jr., "Radionuclide and Heavy Metal Concentrations in Soil, Vegetation, and Fish Collected Around and Within Tsicoma Lake in Santa Clara Canyon," Los Alamos National Laboratory report LA-13144-MS (1996).

Fresquez, P.R., D.H. Kraig, M.A. Mullen, and L. Naranjo, Jr., "Radionuclides and Trace Elements in Fish Collected Upstream and Downstream of Los Alamos National Laboratory and the Doses to Humans from the Consumption of Muscle and Bone," Journal of Environmental Science and Health Part B, B34(5):885-900 (1999a).

Fresquez, P.R., J.D. Huchton, and M.A. Mullen, "Trace Elements, with Special Reference to Mercury, in Fish Collected Upstream and Downstream of Los Alamos National Laboratory," Los Alamos National Laboratory report LA-13658-MS (1999b).

Gilbert, R.O., Statistical Methods for Environmental Pollution Monitoring, Van Nostrand Reinhold, New York, NY (1987). 
Gonzales, G.J., P.R. Fresquez, and J.W. Beveridge, "Organic Contaminant Levels in Three Fish Species Downchannel from the Los Alamos National Laboratory," Los Alamos National Laboratory report LA-13612-MS (1999).

Hakonson, T.E., G.C. White, E.S. Gladney, and M. Dreicer, "The Distribution of Mercury, Cesium-137, and Plutonium in an Intermittent Stream at Los Alamos," Journal of Environmental Quality 9:289-292 (1980).

Hammond, P.B., and E.C. Foulkes, "Metal Ion Toxicity in Man and Animals," In: Concepts in Metal Ion Toxicology, Vol 20, Sigel, H., Ed., Marcel Dekker, Inc., New York, NY (1986).

NMDH (New Mexico Department of Health), "Fish Consumption Guidelines due to Mercury Contamination," NM Department of Health, NM Environment Department, NM Department of Game and Fish (1993).

NMED (New Mexico Environment Department), “A White Paper on Mercury,” New Mexico Environment Department, Surface Water Quality Bureau, Santa Fe, NM (1999).

Ochiai, E., "Toxicity of Heavy Metals and Biological Defense: Principles and Applications in Bioinorganic Chemistry-VII," Journal of Chemical Education 72:479-484 (1995).

Purtymun, W.D., "Storm Runoff and Transport of Radionuclides in DP Canyon, Los Alamos County, New Mexico," Los Alamos Scientific Laboratory report LA-5744-MS (1974).

Stephens, D.B., P.M. Kearl, and R.W. Lee, "Hydrogeologic Review for the Environmental Restoration Program at Los Alamos National Laboratory," LANL Hydrogeology Panel Final Report, Daniel B. Stephens and Associates, Inc., Albuquerque, NM (1993). 
Torres, P., "Metal Accumulation in Various Fish Species from Conchas Lake and Santa Rosa Lake in East Central New Mexico,” M.S. Thesis, New Mexico Institute of Mining and Technology, Socorro, NM (1998). 
This report has been reproduced directly from the best available copy. It is available electronically on the Web (http://www.doe.gov/bridge).

Copies are available for sale to U.S. Department of Energy employees and contractors from:

Office of Scientific and Technical Information P.O. Box 62

Oak Ridge, TN 37831

(865) 576-8401

Copies are available for sale to the public from: National Technical Information Service

U.S. Department of Commerce

5285 Port Royal Road

Springfield, VA 22161

(800) 553-6847 
Los Alamos NATIONAL LABORATORY EST.1943 